phenomena that render aerial navigation dangerous to all classes of aircraft. A form is included, as a detachable page of the pamphlet, to be forwarded to the Director-General by anyone wishing to receive, free of charge, copies of all supplements and new editions as they are issued to cover the inevitable changes and growth of this meteorological service.

\section{Yugoslav Cultural Progress}

LitTuE notice is apt to be taken of the quiet constructive work or scientific developments that go on among the smaller nations. With this fact before it, the Society for Promoting Anglo-Saxon Culture in Yugoslavia has commenced the publication of an Anglo-Yugoslav Review, a quarterly to be devoted to the furtherance of the use of English among Yugoslavs and also to acquaint the British and American peoples with the educational, cultural and general progress of the South Slav nation. Its appearance coincides with the celebrations arranged for the eightieth birthday of Nicholas Tesla (born on July 10 , 1856), which were held at the end of May. Tesla is a Yugoslav by birth, although most of his work and electrical discoveries on alternating and highfrequency currents were made at Paris and in America. A 15,000 horse-power plant of Tesla's conception was erected at Niagara in 1891 to supply power to Buffalo, 25 miles away-a remarkable feat at the time. Indeed, Tesla's fellow-countrymen claim that his work ranks him on a level with Volta, Watt and Faraday. Approximately half the review is devoted to the section on science and invention. Other sections deal with political, economic, sociological and miscellaneous matters, and among these is an account of recent archæological discoveries in Yugoslavia. Among the four British or American contributions is one by Mr. C. H. White, who discusses the cultural consequences when a nation's mineral resources are developed. The review is published in Belgrade, price $10 s$. per annum.

\section{Transmission and Distribution of Electricity}

Is a progress report by C. F. Bolton and R. H. Abell on the transmission and distribution of electricity (J. Inst. Elec. Eng., April) there are several points of special interest. The British Grid uses a pressure of 132 kilovolts, but there is a large number of systems operating at $220 \mathrm{kv}$. in different parts of the world. In Sweden a hydro-electric power station operates over 200 miles at $220 \mathrm{kv}$. In France there is a line at this pressure which brings hydro-electric power to Paris. Great activity has been shown in electric development in Russia, and the Dnieper system operates at the same pressure. The Boulder Dam project on the Colorado River represents one of the outstanding engineering achievements of recent years. A part of the energy developed, $1 \cdot 3$ million kilowatts, will be transmitted 266 miles to Los Angeles by a $287 \cdot 5 \mathrm{kv}$. transmission line. German engineers have constructed several of their $220 \mathrm{kv}$. lines so that they can be converted ultimately to work at $380 \mathrm{kv}$. A scheme using a transmission voltage of $400 \mathrm{kv}$. has been proposed for the establishment of a large water-power station in Norway for supplying power to Sweden, Denmark and Germany. The main transmission system is to be some 650 miles in length. It terminates at Hamburg, and will have intermediate stations at Göteborg and Copenhagen. The generating plant will have a capacity of nearly a million kilowatts (1 34 million horse-power). The British Grid scheme is now completed, and through it, the considerable water-power sources now available in Scotland are being exploited. The problem of 'system stability' arises when large blocks of power are transmitted over long distances. In Great Britain it is not of special significance.

\section{Care of Old Trees}

THE general public probably expresses more sentiment upon the beauty of large trees than upon any other aspect of horticulture. Yew trees may, under good conditions, live to the ripe age of a thousand years, and the oak can boast of very considerable longevity. Whilst the life of a tree must sometime come to an end, the artificial conditions of urban England often shorten its span, unless special care be taken. Mr. A. D. C. Le Sueur has recently shown (J. Roy. Hort. Soc., 61, Pt. 4, 149-159, April 1936) what steps may safely be taken to check decay. Wounds should be cut to healthy wood, treated with a light creosote fungicide, and then rendered waterproof with bitumen. Branches should be cut close to the trunk. Cavity wounds usually contain wood already decayed, and should be cleaned drastically before filling with bitumen or concrete. Artificial support may be given with cables or rods, rather than by bands. Faulty soil conditions, such as lack of nutrients, water or air, or bad drainage, frequently retard good tree growth in public parks. The paper gives many details for the treatment of such backward trees, and provides innumerable instances of scientific practice of the greatest interest.

\section{Earthquake Records at De Bilt, Holland}

TWENTY-ONE years ago, the first number of the Seismische Registrierungen in De Bilt appeared under the editorship of Dr. E. van Everdingen. We have recently received the annual report No. 21 for the year 1933, still issued under the same capable direction. The seismological observatory of De Bilt lies about five miles north-east of Utrecht. In 1904, it contained a pair of Rebeur-Paschwitz pendulums and a Wiechert horizontal seismograph, and, in 1912, a pair of Galitzin horizontal seismographs were installed. In 1933, the same instruments were in action with the addition of a Galitzin vertical seismograph. The bulletin for 1933 contains the records of 450 earthquakes, and it is worthy of notice that, besides the usual details with regard to the times of the principal phases at $\mathrm{De}$ Bilt and the estimated positions of the epicentre, the editor should have been able to collect notices of nearly one-third of these earthquakes from the countries in which they were felt. 